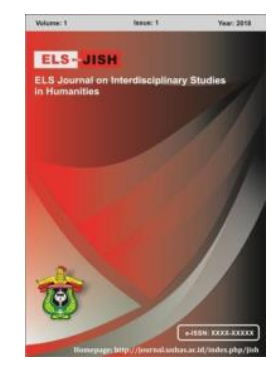

ELS-JISH

ELS Journal on Interdisciplinary Studies on Humanities

Volume 3 Issue 2, 2020

ISSN (print) : 2621-0843

ISSN (online) : 2621-0835

Homepage : http://journal.unhas.ac.id/index.php/jish

\title{
Masculinity Aspects in the Glass Menagerie
}

\author{
Nensia ${ }^{1}$
}

nensia.s@gmail.com

\begin{abstract}
Masculinity is the labeling for men related to sex, identity, responsibility, culture, tradition, and others aspect. Masculinity is also the term of separating position for men from female. The aim of the research was to describe the masculinity values of the men characters in the drama whose name is Tom that he is depressed by his mother. The research employed a descriptive qualitative method with structuralism approach. Data sources were primary and supporting data. The primary data were taken from Tennessee William's The Glass Menagerie, and supporting data were taken from the books, journals, articles, and internet sources. The research indicated masculinity values in this drama had shown man's role as a son, man as an independent man, and man as a friend.
\end{abstract}

Keywords: The Glass Menagerie, Masculinity, Structuralism, Man's Role.

How to cite: Nensia. (2020). Masculinity Aspects in the Glass Menagerie. ELS Journal on Interdisciplinary Studies in Humanities, 3(2), 287-296. DOI: 10.34050/els-jish.v3i2.9616

\section{Introduction}

Drama or called as play is created to give some concepts for representing certain social condition, human's experience, and some realities of life, not only about imagination that released from problem of life that is played on the stages. It is a proof that literary work is not born from inanity, but it is the reflection of the phenomenon had happened or will happen in another time. Therefore, the literary work is related to other studies, such as sociological aspects, psychological effects, structuralism elements, social criticism, historical periods, even gender issues lead to feminism or masculinity.

Masculinity is a set of qualities, characteristics or roles generally considered typical of, or appropriate to, a man. In other words, masculinity is possession of the qualities traditionally associated with men. There are universality masculine images typically convey power, strength, virility, athleticism, competitiveness, and so on. Each man has different needs but the greater power is in the value of a man. We can see it in their own personal behavior and attempt to be as masculine as a man could be. The writer called this as a man personal masculinity. Man can be said to be a man if he has those masculine characteristics. 
As the object, the writer chooses a play by Tennessee William, The Glass Menagerie. It is a four-character memory play. As one of his famous play, The Glass Menagerie was Williams's first successful play which it made himas the American's most highly regarded playwrights. The play is introduced to the audience by fictional character of Tom, the narrator and protagonist, as a memory plays within Tom's mother whose name is Amanda and his sister, Laura.

In the play, the writer finds an interesting fact for the author, Tennessee William, relating to his work, The Glass Menagerie. The play is accounted by sources that it is as if an autobiographical play about Williams's life. The character of Tom is believed as the portray of Tennessee William's himself, as a man living his life in such deppression. He is the only man in his family who has to support the family life. His father abandoned the family.

The writer views men should not be brought up feeling guilt, pain and sorrow for all of the abuse women have taken in history. The men should be raised to be men and part of that is respecting women. The men need to prove their masculinity through domination over women. The way for men to move forward as men is to develop their own norms based on their core masculine characteristics and their response to cultural condition. In other words, the men should create men's own personal masculinity.

From those descriptions, the writer interested to analyze the masculinity aspects in The Glass Menagerie. It often includes masculist theory, men's history and social history, men's fiction, men's health, masculist psychoanalysis and the masculist and gender studies-influenced practice of most of the humanities and social sciences. It relates to the masculinity aspects of the main characters condition in the drama whose name is Tom that he is depressed by his mother, so the writer determines the title of this analysis is Masculinity As It Is Reflected in William's The Glass Menagerie.

\section{Method}

This analysis is possible to categorize the gender study related to the masculinity values in The Glass Menagerie which was written by Tennessee William. Masculism phenomena in the play which is caused by the characters' conflict in the family life as the main problem. The writer uses the structuralism approach to analyze the topic that it stresses on the characters.

The category of this analysis is qualitative research. It presents the object analysis descriptively without using scores or quantitative category. Then, method analysis used by the writer is the descriptive method according to Irawan $(2003: 58)$ that the aim of descriptive method is describing or explaining the whole phenomenon in the object study.

Because of this analysis is focused on the man character, so the data stresses on the play The Glass Menagerie by William Tennessee. It is analyzed by using the methodological analysis of structuralism approach.

\section{Findings}


This analysis is possible to categorize as the gender study relates to the masculinity values inThe Glass Menagerie. According to analysis steps of Structuralism Approach, the writer focuses on the structural aspects analysis.

In this play, there are two men characters that will be discussed, Tom Wingfield and Jim O'Conor. Other man character is the father of Tom Wingfield which will not be discussed because the character does not appear in the play.

\subsection{Tom Wingfield}

Tom has double role in the play, as a character and narrator. We need to be careful in seeing his role. Tom appear as an ambitious man. Tom has a big ambition of adventure. The writer sees that Tom feels bored with his monotone life. Even more he does not like the apartment, the situation of the house, and the job.

Tom: "I go to the movies because I like adventure. Adventure is something I don't have much of at work, so I go to the movies" (Williams, 1973: 763).

From above quotation can be seen that Tom runs away of his bored of his own life to movies in which to find some adventure that he does not get at any of his activity. He goes to the movies in every night. He also goes to the movies when he gets conflict with his mother. It seems that only movies could give him a pleasure of life, a place for him to rest, and a friend to talk to.

The second characteristic is a closed-person. In the play seems that Tom never talk to someone about his real feelings and problems. Even he does not has any friend to go with. He talks a little while his mother talks too much represent him.

Tom: "No. You say there's so much in your heart that you can't describe to me. That's true of me too. There's so much in my heart that I can't describe to you! So let's respect each other" (Williams, 1973: 762).

In this quotation, we can see that Tom does not want to share his pain with anyone. The writer determines that it is become habit for him which he always stands by himself to struggle for his family necessity without reveal his true feelings. Then he said such thing just to make his mother stop digging him for reason.

Even though he is a close person, there is a good point of Tom, caring. When his mother ask him to invite a friend for a dinner, he seems does not care and go away only with a nodding answer. At first he does not want to do that but he feels pity on his mother who has been asking him for several times. Finally, he does invite a friend, Jim O'Conor. The writer also see Tom's caring attitude while he has a big conflict with his mother. He is the one who apologize to his mother while his mother keeps shut her mouth.

Tom: "Mother. I-I apologize. Mother. I'm sorry for what I said, for everything that I said, I didn't mean it"' (Williams, 1973: 762).

It can be seen that Tom has a good understanding as a child that it should be him the first one to apologize. We can see how patient he is under such depression but he still could apologize politely. After apologize, his mother force him again to breakfast while he just want a cup of black coffee. In that situation, 
he still try hard to calm, polite, and ensure to his mother that she is not a bad mother.

Besides caring he is also a responsible man. As the only man in his family, Tom works hard to suffice the family necessity. He works in a warehouse which is not a pleasant job. He does not like his job but he hold on to it because he realizes that he is the only one who could take responsibility of his family. He has a big dream of adventure. He wants to go out to work at a merchant navy. He sacrifices his dreams only for his family. Unfortunately, at the end of the play he abandons his family just like what his father did. It is not at all Tom's fault but Amanda. In the end of the play, Amanda blame Tom for all the bad things happened in their life. Tom could not accept it and Amanda tell him to gone away. Then, he gone away left his family in regret.

\subsection{Jim O'Conor}

Jim O'Conor is a friend of Tom in a warehouse. Jim, Tom, and Laura were in the same high school. Jim has been invited by Tom to come to Wingfield's house for a dinner. The writer determines several characteristics of Jim which will be discussed as follow.

The first, Jim is a polite person. As a man Jim is included into a polite man. When in Wingfield's house, he asks permission to come inside the house, say hello to a new person that he met, and answer question politely. He really knows how to behave toward women.

Jim: "I judge you to be an old-fashioned type of girl. Well I think that's a pretty good type to be. Hope you don't think l'm being too personal. Do you?" (Williams, 1973: 776).

From the quotation above, the writer determines that Jim is a polite man. $\mathrm{He}$ tries to be honest in a polite manner. He dare to make such statement of Laura, then he continues it with an adore to Laura. At last, he asks question which means that he apologizes if he made a mistake.

The second, Jim is a good friend. As we know Tom does not has any fiend in this play. Jim is the only friend for Tom. Jim also accepts Tom's invitation for a dinner in Wingfield's apartment while people know that their apartment is not a luxury one. Jim keeps making friend with Tom even though Tom is only an ordinary man. Jim also has attention about Tom. "In public speaking! You and me, we're not the warehouse type" (Williams, 1973: 772). It means that Jim also care about Tom's future. He asks Tom to join him taking course in public speaking for better job. He has attention that Tom also is not suitable to work at a warehouse. He also keeps call Tom as Shakespeare because he appreciate Tom's ability in making poetry.

Unfortunately, Jim is also a careless one. When he dances with Laura, he crashes the menagerie so it is glass is broken. The worst is he kisses Laura on the mouth while he has a girl named Betty. After all, Jim is a honest man. He 
dares to honest to Laura and Amada that he engages to a girl. He tells Laura that he is in love with that girl.

\section{Discussion}

The masculinity values in the glass menagerie

After doing some analysis above, the writer finds some values of masculinity in this play. As it has been mention that masculinity is the term of separating position for men from women. It uses as the labeling for men relates to sex, identity, responsibility, culture, tradition, and other aspect. Masculinity is not a static that someone has or is since he was born. It is a progress on man mastering his social condition.

The men characters in this play have different progress in reaching their masculinity. Of course, it depends on the efforts of each man in taking role and manages their self to face the world. The main destruction of Tom's life is the family relationship. In family relationship, women are easy to be unstable which may lead to be in depressive situation. Many reasons can cause the instability happens in family life. One of them is for instance, a mother who has to bring up or manage her children alone because the father has left the family without any responsibility to his family. This happens in the play.

Amanda: "Honey, don't push with your fingers. If you have to push with something, the thing to push with is a crust of bread. And chewchew! Animals have sections in their stomachs which enable them to digest food without mastication, but human being are supposed to chew their food before they swallow it down. Eat food leisurely, son, and really enjoy it. A well-cooked meal has lot of delicate flavors that have to be held in the mouth for appreciation. So chew your food and give your salivary glands a chance to function! (Williams, 1973: 753).

Tom: "I haven't enjoyed one bite of this dinner because of your constant directions on how to eat it. It's you that make me rush through meals with your hawk-like attention to every bite I take. Sickening, spoils my appetite all this discussion of animals secretion, salivary glands, mastication!" (Williams, 1945:753)

This quotation described Amanda's way of acting toward Tom is too much. Tom is a mature man. He knows how to behave but it is Amanda that makes him rush through meals. By Tom's constant manner in eating, we can see that he does it in purpose that he try to get away of Amanda's speech in the table. It means that Tom already feel sick of all Amanda's nonsense but he does not say anything only get away. Here, the writer think that Tom as a man does not reach the masculinity of a mature man behavior. He prefers to get away than to face her mother's silliness. It is proved in quotation "I'm getting a cigarette" (Williams, 1973: 753). It means that Tom given up one of the point of masculinity, man personality traits, which man should not be afraid in facing anything because man is a strong human being. Tom always gets away from Amanda and run escaped into cigarette or movies. 
As a man, Tom does not get the pride of being a man, the appreciation, or any aspect that a man could has. "Look l've got no thing, no single thing" (Williams, 1973: 758). Amanda's superiority of all things in the apartment, Tom's behavior, and her children's future make Tom feel does not has anything to be manage or proud of. Even the small thing like Tom's hobby in reading books and poetry get cross over by Amanda. It can be seen below:

Amanda: "I took that horrible novel back to the library, yes! That hideous book by that insane Mr. Lawrence. I cannot control the output of diseased minds or people who cater to them. But I won't allow such filth brought into my house! No, no, no, no, no!" (Williams, 1973: 758).

From both of above quotations show that Tom start to angry when he find out that even his small thing also took over from him. We can see how Tom and Amanda always in different side each other. As a mother, Amanda should open his mind about her children's desire. On that, she can choose if that is good or bad for her children.

Everyone has right to own a hobby, include Tom. He has a medicine of his boring life, adventure books and poetry. It proves that Tom typically romantic and brave man. Unfortunately, he does not brave yet to step on his chosen path, adventure of outside world. He keeps dream on it.

In one opportunity, Tom is finally able to state his feeling to Amanda. It is because the situation in tense between Tom and Amanda. They are always in different idea about something. Amanda always talks too much, cut Tom's word in the middle of conversation, and she always complains of all things about Tom. This time is for once, Tom speeches out his feeling.

Tom: "Listen! You think I'm crazy about the warehouse? You think I'm in love with the continental shoemakers? You think I want to spend fifty-five years down there in that-celotex interior! With fluorescent tubes! Look! l'd rather somebody picked up a crowbar and battered out my brains, than go back mornings! I go! Every time you come in yelling that God damn "Rise and Shine", "Rise and Shine"! I say to myself, "How lucky dead people are!" But I get up. I go for sixty-five dollars a month, I give up all I dream of doing and being ever! And you say self-self's all I ever think of. Why, listen, if self is what I thought of, Mother, l'd be where he is gone! (pointing to father's picture) As far as the system of transportation reaches! (Williams, 1973: 759).

This quotation describes the act that Tom's took is pushed by the temper of his tense conversation with Amanda. He feels tired and suffocated by Amanda's ultimatums about all things. He gives up all his dream to stay in the warehouse to suffice his family necessity but the only thing of his hobby, his books, also is taken from him. Tom is really in depressive condition.

Luckily, he understands his responsibility as the only man in the family. This one shows Tom has some values of what man called as masculinity such as in personality traits and occupation. He keeps work in the warehouse which 
he does not like for his family. That is a heavy work while other men would prefer to work in office or other place. Tom should accept the job at the warehouse as a responsible man, he did. It means that he is a strong man. The good thing is he already set plan about his future. He does not think to stay work in the warehouse for the rest of his life. The writer think this one is called as man think. A good man should prepare himself to face the world because life is changing by days.

However Tom's effort to ensure Laura that he know the best for him, Amanda still hold the superior domination in family. With her stubborn attitude, Tom will never allow doing anything. Even when Tom states his feeling in the quotation above, Amanda does not want to accept. She ask Tom to apologize. "I won't speak to you until you apologize" (Williams, 1973: 759). Here, the writer sees that Tom really never get chance from Amanda. It is only the first time Tom tells the truth about what he had wished. Amanda should has appreciate it because Tom also has rights to state his opinion.

Another conflict between Tom and Amanda is their opinion about adventure. They have different opinion about it. When Tom said that he likes a lot of adventure and most young men does not find adventure in their careers, Amanda replies that most young men find adventure in their careers and not everybody has a craze for adventure. The writer thinks Amanda does her role in wrong way. As a mother, she should understand that Tom is a grown up man even the only man in the family. As in the male role identity, man is independence while woman is dependence. It means Amanda should give Tom the rights to choose his way as long as he still in responsibility of his family. Amanda's attitude makes them in conflict for several times when Tom cannot hold to struggle his opinion.

Tom: "Man is by instinct a lover, a hunter, a fighter, and none of those instincts are given much play at the warehouse (Williams, 1973: 763).

This quotation show that Tom does not feel as a real man by working in the warehouse. He does not get his sense of being a man. He wants to be a man who is a lover, a hunter, a fighter. It means he wants to be a gentle man which daring, aggression, self-reliance, and a caring as well. He wants to get out of the warehouse and find other job who would give him his expectation while Amanda is in opposite position.

Amanda: "Man is by instinct! Don't quote instinct to me! Instinct that something of people have got away from! It belongs to animals! Christian adults don't want it! (Williams, 1973: 763).

Both of these quotations describe how different Tom and Amanda are! Amanda shows her selfishness that Tom should not quote instinct to her. As Tom mention above about his opinion of being a man, lover, means that he loves his family. Even though he is quit of the warehouse, he would be responsible to suffice his family necessity by working in other place. Then, Amanda should understand about this thing. Here, we can see how Amanda does not care of Tom's feeling and desire. 
Tom's effort is never appreciated by Amanda. If Tom is a selfish man, he will not apologize to Amanda and stay work in the warehouse for his family. As a man, Tom is a cool typical while woman talks too much. By Amanda's constant statement, he does not take care or angry of it. He walks away to go to work. He is good in keeping his emotion stabile.

The writer thinks that deep inside Tom's heart, he is a gently heart man. Every time Amanda talks about Tom is being his father, Tom get away to smoke suddenly. The writer sees this as an escaped of Tom to get rid from the more depression of his father's left. From the outside, he seems does not care of his family, but inside he hurts so deep. It is proved in quotation, "I'm like my father. The bastard son of a bastard! See how he grins? And he's been absent going on sixteen years" (Williams, 1973: 773). This quotation shows Tom's confidence is disappear. He starts to believe that he is a bastard as his father did. It is because of Amanda keeps on saying such thing and never appreciates Tom's efforts. While Tom's left, he feels incomplete. He keeps on think about Laura. He regrets to leave Laura's behind. It is proved that he has a nice heart but Amanda turn it into wrong direction.

Even though Tom is not a good enough for Amanda, Tom still understands his position as a child of Amanda. He keep respects to Amanda by fulfill all Amanda's request such as to bring a friend for a dinner and all Amanda's critics on Tom's appearance. The most patient attitude of Tom is when Amanda compares Tom's salary with Jim's salary. He does not say any offensive word. Amanda should be graceful of Tom's effort to be responsible as the only man in the family.

Not only in the family, but also in the workspace Tom does not get any acknowledgement. Down at the warehouse, other people underestimate him. As in the masculinity theory, man needs status, the thing that Tom does not have one. The writer sees how great the character Tom taking role as a man. He could manage his emotion. He should be depressed but he shows the appearance of calm man. He is smart to bring all his suffocating to movies. He entertains himself by digging adventure in movies.

Luckily, there is a nice young man who appreciates Tom as a Shakespeare. His name is Jim O'Conor. He heals Tom's depression of suspicious hostility at the warehouse. Jim was a famous hero in the high school. They were in the same school, Tom, Jim, and Laura. Jim is champion of basket, debating, and many other things. By his well known record, he wants to make friend with Tom, the unknown man. It shows Jim has the value of real good man as a friend. He is the real gentleman who is not being proud of his famous record. Even, he chooses to be the best friend of Tom.

Jim: "In every! Ask yourself what is the difference between you and me and men in the office down front? Brains? No! Ability? No! the what? Just one little thing- primarily it amounts to social poise! Being able to square up to people and hold your own on any social level! (Williams, 1973: 763).

This quotation shows how Jim cares about his friend, Tom. In masculinity also there is point of the value of a man in social environment. Jim shows this 
value. He asks Tom to join him in public speaking course to make them behave to connect with people at any social level. That way they will get up high on any social level.

As the writer had mention on the characters part above that Jim is a polite man. He is also a smart and good man. He really knows how to carry on himself in front of people. He wants to help Amanda on the dishes, knows how to be humorous, and he really knows how to talk as well. As he say, "candlelight is my favorite kind of light" (Williams, 1973: 775). The writer determines that he is a romantic man. It is such a rare for a man to have attention on such thing. Moreover, he feels Laura is beautiful while we know Laura is not quite beautiful.

This drama describes how Jim does not see the beauty of a girl from the cover. He sees the beauty in each Laura parts of body and soul, in Laura's eyes, hair, and hand as well. Even he notices that Laura needs help to build up her confidence. At the first meeting, he already what is happened to Laura and what Laura needs to. It means that Jim is a caring man. Unfortunately, the nature man about girl is in himself while he could not get away from kissing Laura. He feels to regret in doing that. It is proved in the quotation,

Jim: “No, Laura, I can't. As I was just explaining, l've got strings on me, Laura, I've been going steady! I go out all the time with a girl named Betty. She is a home girl like you, and chatolic, and irish, and in great many ways we get along fine" (Williams, 1973: 781).

As we can see in this quotation is the masculine of Jim. He is a honest man. He already kisses Laura but he dares to admit that he already engage to a girl. He does not want to hurt anybody so he tells the truth. Even he dares to admit it to Amanda. While he ask permit to be going, he mention the reason is Betty. He is an example of a good manner of a man.

\section{Conclusion}

Based on the research result, the writer may conclude that the men characters, Tom Wingfield and Jim O'Conor, have experiences each role as a man. A man and woman are growing up by values and rules in a culture that reflects the important of being separated from others in man's life and the important of being connected to others in woman's life. The stressing of being connected to others in men's life forms them to develop moral value in selfconfident, independence, aggressive, ambition, strength, and care. The ethics of care reflects men's roles and characters as responsibility, self-sacrifice, daring, and unafraid. It is the description of the hidden power of man's masculinity.

In this play, the writer applied man's role as a son, man as an independence man, and man as a friend. Tom takes role as a son which he has to agree with all Amanda's instruction even it is about his appearance which drive Tom into depression. The worst is Amanda's overbearing and superiority in manage her children which make Tom far away of being independence man. It makes Tom would run away for adventure is Amanda's attitude which never appreciate Tom's effort for the family. Then, the man role as a friend is taken by Jim O'Conor who is the only good friend of Tom. 
Unfortunately, Jim makes a mistake by kissing Laura but then he realizes that he is wrong. So, he apologizes to Laura and Amanda. He also honest to them that he already engages to a girl named Betty. The writer sees Jim success in taking role as a responsible man who honest to tell the truth which actually hard to be revealed after he kisses Laura. In the end of the play, Tom finally left the family after conflict with Amanda. He lefts in regretting of Laura. He knows that he took the wrong decision but he could not back to the family. He feels terribly worry about Laura being abandoned. It shows the role of Tom as a lover. Unfortunately, it is also show the failure of Tom in reaching other point of a man's role which is man as decision maker.

\section{References}

Bradley, R. M. (2008). Masculinity and Self Perception of Men Identified as Informal Leaders. ProQuest.

Deardoff, D. L. (2006). Hero and Anti-Hero in the American Football Novel: Changing Conceptions of Masculinity from the Nineteenth Century to the Twenty-First Century New York: The Edwin Mellen Press.

Dukore, B. F. (1974). Dramatic Theory and Criticism: Greek to Grotowsky. New York: Holt Reinhart and Winston.

Ehrenhaft, G. (1985). Barron's Book Notes Tennessee Williams's The Glass Menagerie \& A Streetcar named Desire. New York: Barron's Educational Series, Inc.

Hawkes, T. (1978). Structuralism and Semiotics. Methuen \& Co. Ltd: London.

Leverich, L. (1955). Tom the Unknown Tennessee Williams. New York: Crown Publishers.

Ley, G.. (1959). The Ancient Greek Theater. Chicago: University of Chicago

Meyer, R. (1991). Classical Drama, Greek and Roman. New York: Barrons

Reaske, C. R. (1966). How to Analyze Drama. Department of English Harvard University: Monarch press.

Hoffman, R. M. (2001) The Measurement of Masculinity and Femininity: Historical Perspective and Implications for Counseling Journal of Counseling and Development 79: 472.

Williams, T. (1945). The Glass Menagerie. Copyright 1945 by Tennesse Williams and Edwina D Williams and renewed 1973 by Tennessee Williams reprinted by permission of Random House, Inc 